УДК 341.231.14:(316.48:623.44)(477)

DOI https://doi.org/10.32849/2663-5313/2021.3.51

\title{
Мальвіна Грушко,
}

канд. юрид. наук, доцент,

доцент кафедри міжнародного та європейського права

Начіонального університету «Одеська юридична академія»

Катерина Мануїлова,

канд. юрид. наук, дочент,

доцент кафедри міжнародного та європейського права

Національного університету «Одеська юридична академія»

\section{КОНЦЕПЦІЯ ПЕРЕХІДНОГО ПРАВОСУДДЯ В УМОВАХ ЗБРОЙНОГО КОНФЛІКТУ В УКРАЇНІ}

Стаття присвячена дослідженню кониепиї̈ перехідного правосуддя та ї̈ значення для Украӥни. Авторами було проаналізовано можливість впровадження концепиії перехідного правосуддя в Україні. Збройний конфлікт в Україні триває вже сьомий рік і наразі зафіксовано величезну кількість випадків порущень прав людини та скоєння численних воєнних злочинів. Тому нині одним із пріоритетних напрямів державної політики має бути притягнення до відповідальності осіб, які скоїли воєнні злочини в умовах збройного конфлікту. Шляхи вирішення иих та інших супутніх проблем вбачаються саме у впровадженні механізму перехідного правосуддя.

У міжнародних документах перехідне правосуддя визначається як комплекс прочесів та механізмів, пов'язаних зі спробами суспільства подолати тяжкі наслідки масштабних порушень законності в минулому з метою забезпечити підзвітність, справедливість і примирення. Ключовим елементом концепиії є питання про притягнення до відповідальності осіб, винних у вчиненні воєнних злочинів. Це питання можна вважати «наріжним каменем» концепції, адже покарання винних є, по-перше, засобом встановлення справедливості, а по-друге, запорукою неможливості виникнення подібного конфлікту в майбутньому.

Основними засадами начіональної кониепиї перехідного правосуддя в Україні є чотири елементи: реалізація права знати правду про перебіг подій конфлікту; інституиійні реформи як гарантія не повторення збройного конфлікту; заходи з відшкодування шкоди потерпілим від збройного конфлікту; притягнення до відповідальності осіб, винних у скоєнні найтяжчих злочинів. Для ефективної реалізації концепиії перехідного правосуддя всі чі елементи повинні пращювати в комплексі.

Концепиія перехідного правосуддя - майже єдиний спосіб, який дозволить не тільки подолати тяжкі наслідки збройного конфлікту, а й забезпечити відновлення порушених прав і притягнути до відповідальності винних у скоєнні злочинів. Оскільки кониепиія є комплексом прочесів та механізмів, які пов'язані зі спробами суспільства подолати великомасштабні порушення прав людини і міжнародного гуманітарного права, то частиною такого процесу також має стати імплементація у національне законодавство норм міжнародного гуманітарного права та міжнародного кримінального права. Важливим є запозичення досвіду країн, чиї стратегії перехідного правосуддя засновані на повазі прав людини виправдали себе, виконання належних міжнародно-правових зобов'язань держави і визнання відповідних порушень з боку учасників усіх сторін конфлікту.

Ключові слова: права та свободи людини, воєнні злочини, концепція, перехідне правосуддя, збройний конфлікт, постконфліктний період.

Постановка проблеми. Світова практика передбачає запровадження механізму перехідного правосуддя у постконфліктний період. Збройний конфлікт в Україні триває вже сьомий рік і наразі зафіксовано величезну кількість випадків порушень прав людини та скоєння численних воєнних злочинів. Тому нині одним із пріоритетних напрямів державної політики має бути притягнення до відповідальності осіб, які скоїли воєнні злочини в умовах зброй- ного конфлікту. Шляхи вирішення вказаної та інших супутніх проблем вбачаються саме у впровадженні механізму перехідного правосуддя. Очевидно, що інституційні реформи в Україні, впровадження правових проектів переслідування воєнних злочинців, а також законодавче закріплення механізмів надання компенсації жертвам конфлікту та інші дії призведуть до гуманітарного діалогу для пошуку примирення в українському суспільстві. 
Аналіз основних досліджень та публікацій. 3 огляду на те, що в Україні наразі активно відбувається процес розробки концепції перехідного правосуддя, цьому питанню присвячені праці таких вітчизняних вчених, практиків, політиків, як А. Багінський, А. Бущенко, М. Гнатовський, С. Закірова, А. Кориневич, Т. Короткий, О. Мартиненко, О. Плотніков, О. Резніков тощо. Проте натепер залишається велика кількість питань, які не вирішені і потребують подальшого аналізу та розкриття.

|| Мета статті полягає в дослідженні та аналізі актуальних питань, пов'язаних із концепцією перехідного правосуддя.

Виклад основного матеріалу. У міжнародних документах Європейського союзу та Організації Об'єднаних Націй перехідне правосуддя визначається так: «комплекс процесів та механізмів, пов'язаних зі спробами суспільства подолати тяжкі наслідки масштабних порушень законності в минулому з метою забезпечити підзвітність, справедливість і примирення» [1]. До того ж варто наголосити, що міжнародним досвідом не сформовано єдиної концепції перехідного правосуддя, тому впровадження певної моделі в кожній країні завжди буде мати свої певні особливості, які будуть залежати від особливостей країни, суспільства, етнічних, релігійних і гендерних чинників.

Основними засадами національної концепції перехідного правосуддя в Україні $€$ чотири елементи:

- реалізація права знати правду про перебіг подій конфлікту; встановлення правди є частиною концепції і має на меті забезпечення права потерпілих та їхніх родин знати правду про обставини скоєння порушень та долю осіб, що загинули чи зникли безвісти під час таких порушень. Організація і діяльність комісії з розслідування та встановлення правди, а також забезпечення доступу до архівів є реалізацією права на інформацію, яке є одним з основоположних прав людини, що, на нашу думку, стане гарантією запобігання безкарності;

- інституційні реформи як гарантія не повторення збройного конфлікту;

У такому розумінні цю концепцію можна сприймати як превентивний підхід. На нашу думку, подолання безкарності, тобто суспільно-історичне осмислення порушень прав людини і покарання винних, призведе до відновлення верховенства права і забезпечення його довгостроковості в майбутньому;

- заходи з відшкодування шкоди потерпілим від збройного конфлікту; відшкоду- вання шкоди потерпілим включає в себе реституції, репарації, компенсації моральних та матеріальних збитків, психологічну реабілітацію, увічнення пам'яті загиблих у збройному конфлікті та вибачення винних перед потерпілими. На нашу думку, зазначений елемент є досить складним та вимагає певної деталізації. Зокрема, виникають питання щодо прав та обов'язків, що випливають із зобов'язань відшкодовувати шкоду (зокрема, компенсації за майно, пошкоджене/зруйноване за наслідками подій на сході України, починаючи з 2014-го року), порядку відшкодування збитків, щодо того, чи буде надаватися вказаній процедурі гласність, а також питання, пов'язані 3 інституалізацією відповідного процесу відшкодування шкоди, а саме реформи законодавства, державних органів, із соціальною реінтеграцією дітей та іншими заходами;

- притягнення до відповідальності осіб, винних у скоєнні найтяжчих злочинів, базується на тому, що держава застосовує загальні стандарти належного правосуддя, які розроблені міжнародним співтовариством та втілені в нормах міжнародного права.

Для ефективної реалізації концепції перехідного правосуддя всі ці елементи повинні працювати в комплексі.

Правосуддя перехідного періоду включає в себе широкий за обсягом і змістом комплекс заходів, які покликані сприяти державі і суспільству перейти від масштабних порушень прав людини до сталого миру та верховенства права. Зокрема, це такі дії, як розпуск воєнізованих груп, відміна правових норм, прийнятих в період збройного конфлікту і звільнення високопосадовців, відповідальних за серйозні порушення прав людини, питання щодо юридичних механізмів компенсації майнової шкоди потерпілим від збройного конфлікту та окупації, а також стосовно розробки сучасної системи верифікації особистих даних громадян України, які проживають на тимчасово окупованих територіях Донецької і Луганської областей та Криму. Ці заходи можуть бути ефективними лише за умови їх одночасного та паралельного застосування і сприятимуть подоланню наслідків збройного конфлікту.

Аналізуючи питання перехідного правосуддя, керівник аналітичного напряму Української Гельсінської спілки з прав людини О. Мартиненко наголошує: «Для України об'єктивно необхідна розробка власної національної моделі такого правосуддя, щоб почати діалог з усіма громадянами, які постраждали в результаті конфлікту і окупації. Ухвалення перехідного правосуддя дозволить розробити стратегію розвитку 
України на кілька років як гарантію досягнення стійкого миру і дотримання прав людини на окупованих територіях після їх звільнення. Не буде помилкою сказати, що наближення закінчення війни відповідає запиту більшості населення України. Діючи в рамках перехідного правосуддя, Україна має всі шанси вийти 3 конфлікту найбільш цивілізованим способом, одночасно дотримуючись принципів політики Свропейського Союзу та з огляду на Мінські домовленості. Безсумнівно, така комбінація допоможе гармонізувати міжнародні відносини в регіоні і буде сприяти інвестиційному клімату» [2].

Глава представництва президента в АР Крим Антон Кориневич зазначає, що «перехідне правосуддя зосереджено не тільки на юридичних процесах і кримінальному праві, але і на відновлення історичної справедливості після закінчення конфлікту. У концепції передбачено створення Комісії правди - структури, яка б неупереджено збирала інформацію про війну, іï перипетії, розповідала б про реальний стан справ на початок конфлікту, про його героїв та антигероїв. < ..> Це повинен бути або новостворений орган або, враховуючи проблему витрати бюджетних коштів на створення нової інституції, ці функції можна покласти на вже існуючий держорган». Важливим елементом перехідного правосуддя є також питання виплати компенсацій цивільному населенню за завданий в ході війни збиток. Українська концепція передбачає, що буде створений якийсь фонд, який буде займатися цими виплатами [3].

Національна модель перехідного правосуддя для України - це відповідь на питання: як вийти із ситуації окупації та збройного конфлікту та перейти до стану миру. Концепція, по суті, є частиною стратегії деокупації та реінтеграції громадян України.

Окремої уваги заслуговує думка М. Гнатовського: «Треба розуміти, що ми опинилися у достатньо рідкісній ситуації, тому що Україна на момент виникнення збройного конфлікту взяла на себе всі можливі зобов'язання європейської держави у сфері прав людини, у сфері міжнародного гуманітарного права, i, загалом, навіть у сфері міжнародного кримінального права» [4]. Справді, аналізуючи різні погляди та підходи вчених міжнародників, потрібно зазначити, що правосуддя перехідного періоду в Україні $\epsilon$ необхідним складником і основним вектором державної політики для вирішення військового конфлікту. Дана концепція може застосовуватися не тільки після закінчення військового конфлікту, але й з перших днів, коли початок агресії спровокував грубі пору- шення прав людини та норм міжнародного гуманітарного права.

Ключовим елементом концепції $\epsilon$ питання про притягнення до відповідальності осіб, винних у вчиненні воєнних злочинів. Це питання можна вважати «наріжним каменем» концепції, адже покарання винних є, по-перше, засобом встановлення справедливості, а по-друге, запорукою неможливості виникнення подібного конфлікту в майбутньому.

Наразі Верховна Рада прийняла за основу проект Закону України про внесення змін до деяких законодавчих актів України щодо імплементації норм міжнародного кримінального та гуманітарного права (проект Закону № № 913-IX від 17.09.2020). Чинним Кримінальним кодексом України відповідальність за воєнні злочини передбачена статтею 438, але норми даної статті не містять повний перелік тих діянь, які можна кваліфікувати як воєнний злочин, що $є$ порушенням принципу правової визначеності. Законопроектом передбачено викласти цю статтю Кримінального кодексу у новій редакції, що містить статті $438^{1}-438^{5}$, в яких деталізовано викладено різновиди злочинів, зазначених у 8 статті Римського статуту, а також низка порушень Женевських конвенцій про захист жертв війни 1949 р. та Додаткових протоколів до них. Прийняття таких змін до Кримінального кодексу було би позитивним кроком для правильної кваліфікації злочинів у майбутньому. Здійснення правосуддя щодо вчинених злочинів є умовою встановлення миру, утвердження цінностей демократичного суспільства і верховенства права. Ця теза покладена в основу робочого поняття перехідного правосуддя, запропонованого ООН Відповідно до нього правосуддя перехідного періоду охоплює собою повний набір процесів і механізмів, пов'язаних із намаганнями суспільства примиритися зі спадщиною масштабних зловживань минулого і спрямованих на забезпечення підконтрольності, справедливості і примирення.

Наразі Міністерство з питань реінтеграції тимчасово окупованих територій завершило розробку законопроекту, який визначає особливості державної політики перехідного періоду щодо тимчасово окупованих територій у Донецькій і Луганській областях та в Криму. Даний документ спрямований на розгляд для надання пропозицій центральним органам виконавчої влади, держслужбам і фондам, місцевим органам влади, науковим, міжнародним і громадським організаціям, експертному середовищу, судовим органам, прокуратурі, органам військового управ- 
ління, представництва Президента України в АРК та іншим.

Слід зазначити, що серед причин незадовільного стану притягнення до відповідальності за злочини, вчинені в Україні в рамках збройного конфлікту, є, зокрема, недосконалість чинного законодавства України щодо регулювання відповідальності за міжнародні злочини, брак досвіду правоохоронців та суддів у притягненні до відповідальності за порушення норм міжнародного гуманітарного права, відсутність доступу до території, що ускладнює процес збору доказів [5, с. 164].

На нашу думку, ще одним питанням, яке стосується концепції перехідного правосуддя, є створення відповідних органів, до компетенції яких входила б можливість розглядати міжнародні злочини, зокрема воєнні злочини. Міжнародна практика свідчить, що зазвичай розглядом таких справ займались спеціально створені суди. В Україні розглядається можливість створення так званого «гібридного суду», який може містити міжнародний елемент [6], проте реалізація такого підходу може мати деякі труднощі через необхідність внесення змін у національне законодавство.

Потрібно розуміти, що будь-яка домовленість про відмову від карного переслідування суперечить не тільки розвиненій міжнародній практиці, але й цілям, які переслідуе ООН. Зокрема, ООН рішуче орієнтована на підтримку таких мирних угод, які забезпечують можливості для виконання обов'язків і заходів перехідного правосуддя у постконфліктний та перехідний періоди. А тому йдеться про переслідування не за всі порушення прав людини, а тільки за серйозні, зокрема катування, жорстокість, нелюдяне і принижуюче гідність поводження, рабство, насильницьке зникнення та інші. Цей перелік також не є вичерпним, він показує, що в даному контексті існує проблема доцільного розмежування. Нині у суспільстві найчастіше обговорюється питання: яка саме категорія осіб має бути притягнена до відповідальності, а яка може бути амністована. За словами розробників концепцій, остання абсолютно точно передбачає, що амністія не може стосуватися осіб, які скоїли воєнні злочини і порушили норми міжнародного гуманітарного права. Оскільки міжнародна практика рекомендує обмежитися лише категорією воєнних злочинців та винними в грубих порушеннях прав людини, це положення не влаштовуе тих фахівців, які радикально пропонують притягнути до кримінальної відповідальності досить широке коло тих, хто зараз працює в органах окупаційної влади в Автономній Республіці Крим та так зва- них ДНР/ЛНР [7]. Завдання має полягати в тому, щоб визначити, які вчинки не можуть бути виправдані насильницькою формою врегулювання конфлікту i, таким чином, у спільних інтересах, зокрема в інтересах комбатантів, повинні переслідуватися карним кримінальним правом. Удосконалити цей процес можливо також завдяки ратифікації Римського статуту, який надав би нам більше прав у міжнародних інстанціях. Тому ці питання надзвичайно важливі та потребують відповідної уваги та вирішення.

\section{Висновки}

Резюмуючи вищевикладене, можна зробити висновок, що концепція перехідного правосуддя - майже єдиний спосіб, який дозволить не тільки подолати тяжкі наслідки збройного конфлікту, а й забезпечити відновлення порушених прав і покарати винних у скоєнні злочинів. Оскільки концепція $€$ комплексом процесів та механізмів, які пов'язані зі спробами суспільства подолати великомасштабні порушення прав людини i міжнародного гуманітарного права, то частиною такого процесу також має стати імплементація у вітчизняне законодавство норм міжнародного гуманітарного права та міжнародного кримінального права. Лише диференційоване застосування інструментів перехідного правосуддя з чітким усвідомленням його можливостей та певних обмежень в рамках мирного врегулювання може поновити довіру до громадських та державних інституцій в Україні, а також сприяти процесу трансформації конфлікту.

Також є важливим запозичення досвіду країн, чиї стратегії перехідного правосуддя, засновані на повазі прав людини, виправдали себе, виконання належних міжнародно-правових зобов'язань держави і визнання відповідних порушень з боку усіх сторін конфлікту. Проголошення пріоритету змісту універсальних та регіональних міжнародних стандартів у сфері прав людини та громадянина та їх захист з боку держави створить значний плацдарм для системи справедливого та ефективного правосуддя в Україні та належної допомоги постраждалим від збройних конфліктів.

\section{Список використаних джерел:}

1. Доклад Генерального секретаря Объединенных Наций «Господство права и правосудие переходного периода в конфликтных и постконфликтных обществах», (S/2004/616, 23 август 2004). URL: https://undocs.org/ru/S/2004/616 (дата звернення: 10.02.2021).

2. Мартиненко О. Переходное правосудие основа деоккупации и реинтеграции Донбасса. 
URL: http://www.golos.com.ua/rus/article/324612 (дата звернення: 10.02.2021).

3. Кориневич А. Амнистия не для всех: каким будет переходное правосудие на Донбассе и в Крыму. URL: https://daily.rbc.ua/rus/ show/amnistiya-vseh-kakim-budet-perehodnoepravosudie-1597054850.html (дата звернення: 10.02.2021).

4. Гнатовський М. Модель перехідного правосуддя в Україні. URL: https://yur-gazeta.com/ publications/practice/inshe/model-perehidnogopravosuddya-v-ukrayini.html (дата звернення: 15.02.2021).

5. Червякова О. В. Відповідальність за воєнні злочини: через перехідне правосуддя до сталого миру та безпеки України. Проблеми законності.
2020. Вип. 150. С. 161-172. URL: https://doi.org/ 10.21564/2414-990x.150.208602 (дата звернення: 10.02.2021)

6. Секретар РНБО України О. Данілов провів робочу зустріч із заступником Генерального прокурора Г. Мамедовим. URL: https://www.rnbo. gov.ua/ua/Diialnist/4684.html (дата звернення: 17.02.2021).

7. Закірова С. Перехідне правосуддя: сутність концепції, світова практика та уроки для України. Громадська думка про правотворення. 2019. № 19-20 (184-185). C. 2-16. URL: http://nbuviap. gov.ua/index.php?option $=$ com content\&view $=a$ rticle\&id=4679:perekhidne-pravosuddya-sutnistkontseptsiji-svitova-praktika-ta-uroki-dlya-ukrajini2\&catid=71\&Itemid=382 (дата звернення: 17.02.2021).

Malvina Hrushko, Kateryna Manuilova. The concept of transitional justice in the context of the armed conflict in Ukraine

The article is devoted to the study of the concept of transitional justice and its significance for Ukraine. The authors analysed the possibility of implementing the concept of transitional justice in Ukraine. The armed conflict in Ukraine has been going on for seven years now and a huge number of cases of Human Rights violations and numerous war crimes have been recorded so far. Therefore, today one of the priorities of public policy should be to bring to justice those who committed war crimes in the context of armed conflict. Ways to solve these and other related problems are seen through the introduction of a mechanism of transitional justice.

International instruments define transitional justice as a set of processes and mechanisms associated with society's attempts to overcome the grave consequences of large-scale violations of the rule of law in the past in order to ensure accountability, justice and reconciliation. A key element of the Concept is the issue of bringing to justice those guilty of war crimes. This issue can be considered the "cornerstone" of the Concept, because the punishment of the guilty is, firstly, a means of establishing justice, and secondly, a guarantee of the impossibility of such a conflict in the future.

The main principles of the national concept of transitional justice in Ukraine there are four elements: the realization of the right to know the truth about the events of the conflict; institutional reforms as a guarantee of non-recurrence of armed conflict; measures to compensate victims of armed conflict; bringing to justice those guilty of committing the most serious crimes. For the effective implementation of the concept of transitional justice, all these elements must work together.

The concept of transitional justice is almost the only way that will not only overcome the grave consequences of the armed conflict, but also ensure the restoration of violated rights and bring to justice those responsible for the crimes. Since the Concept is a set of processes and mechanisms associated with society's attempts to overcome large-scale violations of Human Rights and International Humanitarian Law, the implementation of International Humanitarian Law and International Criminal Law into national law should also be part of such a process. It is important to learn from the experience of countries whose transitional justice strategies based on respect for human rights have paid off, to fulfill the relevant international legal obligations of the state and to recognize the relevant violations by all parties to the conflict.

Key words: human rights and freedoms, war crimes, concept, transitional justice, armed conflict, postconflict period. 